\title{
HUBUNGAN SIKAP DAN PERAN TEMAN SEBAYA DENGAN PERILAKU SEKSUAL PADA REMAJA
}

\author{
Chandra Sulistyorini ${ }^{1}$, Desi Ayu Wardani ${ }^{2}$, Diar Debita Sari ${ }^{2}$ \\ ${ }^{1}$ Program Studi Sarjana Kebidanan ITKES Wiyata Husada Samarinda \\ ${ }^{2}$ Program Studi Sarjana Ilmu Keperawatan ITKES Wiyata Husada Samarinda
}

Email : chandrasulistyorini@itkeswhs.ac.id,desywardani235@gmail.com,diardebitasari@gmail.com

\begin{abstract}
ABSTRAK
Pada masa remaja, hormon-hormon yang mulai berfungsi selain menyebabkan perubahan fisik juga mempengaruhi dorongan seks pada remaja. Perilaku seksual pranikah merupakan segala tingkah laku yang didorong oleh hasrat seksual baik yang dilakukan sendiri, dengan lawan jenis maupun sesama jenis tanpa ada ikatan pernikahan. Tujuan penelitian ini adalah menganalisis hubungan sikap dan peran teman sebaya dengan perilaku seksual pada remaja. Penelitian ini dilakukan pada Bulan Juni 2020 dengan menggunakan desain penelitian analitik korelasi dengan pendekatan cross-sectional. Teknik sampling penelitian ini menggunakan stratified random sampling dengan menggunakan aplikasi random generator memasukkan nomor responden yang sudah bersedia mengisi di gogglefrom dengan jumlah sampel sebanyak 129 Orang. Hasil Penelitian ini menunjukan bahwa tidak ada hubungan yang signifikan antara sikap dengan perilaku seksual pada remaja dari hasil Chi-square p-value $>0,05$ akan tetapi terdapat hubungan yang signifikan antara peran teman sebaya dengan perilaku seksual remaja Chi-square p-value $<0,05$. Diharapkan dengan penelitian ini remaja akan lebih selektif dalam memilih teman sebaya sehingga tidak terjadi perilaku seksual yang menyimpang pada mereka.
\end{abstract}

Kata Kunci : perilaku seksual, sikap, teman sebaya

\section{PENDAHULUAN}

Masa remaja merupakan bagian dari tahapan pertumbuhan dan perkembangan dari anak menuju dewasa. Pada tahap ini, anak mengalami percepatan pertumbuhan, perubahan hormonal, kognitif dan emosional. Hormonhormon yang mulai berfungsi selain menyebabkan perubahan fisik juga mempengaruhi dorongan seks pada remaja. Remaja mulai merasakan dengan jelas meningkatnya dorongan seks dalam dirinya, diantaranya muncul ketertarikan dengan orang lain dan keinginan untuk mendapatkan kepuasan seksual. Kematangan organ reproduksi dan perkembangan psikologis remaja yang mulai menyukai lawan jenisnya serta mudahnya mendapatkan berbagai informasi baik elektronik

maupun non elektronik akan sangat berpengaruh terhadap perilaku seksual individu remaja (Zakiah, 2020).

Survei demografi dan kesehatan Indonesia (SDKI) tahun 2017 didapatkan 80\% wanita dan $84 \%$ pria melaporkan pernah berpacaran. Kelompok umur 15-17 tahun merupakan umur pertama mulai pacaran pertama kali yang paling banyak disebutkan yaitu $45 \%$ pada wanita dan $44 \%$ pada pria. Persentase wanita dan pria menurut perilaku seksual, mulai tahap berpegangan tangan merupakan hal yang paling banyak dilakukan oleh wanita dan pria (64\% dan 75\%). Pria cenderung lebih banyak melaporkan perilaku seksual cium bibir (50\%) dan 
berpelukan (33\%) dibandingkan dengan wanita (30\% dan 17\%) (Kemenkes, 2018).

Penyebab perilaku seksual pada remaja antara lain: faktor personal: pengetahuan, sikap terhadap layanan kesehatan, gaya hidup, pengendalian diri, aktifitas sosial, rasa percaya diri dan variable demografi seperti, usia, agama; karakteristik lingkungan, antara lain akses dan kontak dengan sumber informasi, social budaya, nilai dan norma sebagai pendukung social untuk perilaku tertentu, karakteristik keluarga: status orang tua dan pendidikan orang tua; karakteristik teman sebaya antara lain perilaku seksual teman sebaya (Nurwati \& Parellangi, 2019).

Dampak yang diakibatkan oleh perilaku seksual yang menyimpang antara lain timbulnya masalah psikologis yang sangat serius, seperti rasa bersalah, depresi, marah, kebingungan akan peran sosial yang tiba-tiba berubah, misalnya pada kasus remaja yang hamil diluar nikah. Belum lagi tekanan dari masyarakat yang mencela dan menolak keadaan tersebut, Selain itu resiko yang lain adalah terganggunya kesehatan yang bersangkutan, resiko kelainan janin dan tingkat kematian bayi yang tinggi. Disamping itu penolakan sekolah menerima kenyataan adanya murid yang hamil diluar nikah. Masalah ekonomi juga akan membuat permasalahan ini menjadi semakin rumit dan kompleks (Misrina \& Safira, 2020).

Sikap remaja terhadap perilaku seksual respon tertutup yang tidak dapat dilihat langsung, sehingga remaja yang mempunyai sikap positif terhadap perilaku seks maka berpotensi untuk berperilaku positif cukup besar pula. Remaja yang berperilaku menyimpang dipengaruhi oleh sikap dan peran teman sebaya terkait seksual, yang berarti niat remaja untuk melakukan perilaku seksual yang menyimpang atau beresiko disesuaikan dengan sikap dan perubahan remaja tersebut (Mariani \& Murtadho, 2018). Teman sebaya sebagai lingkungan yang dekat dengan kehidupan remaja memainkan peran yang signifikan salah satunya dalam hal seksualitas. Jika seorang remaja memiliki teman yang aktif secara seksual maka akan semakin besar pula kemungkinan remaja tersebut untuk aktif secara seksual mengingat bahwa pada usia tersebut remaja ingin diterima oleh lingkungannya. Pengaruh teman sebaya membuat remaja mempunyai kecenderungan untuk memakai norma teman sebaya dibandingkan norma sosial yang ada. Norma-norma seksual teman sebaya mempengaruhi sikap dan perilaku individu remaja. Hal ini merupakan aspek yang harus diperhitungkan ketika menyusun program pencegahan mengenai seksualitas remaja (Andriyani, 2018).

Berdasarkan hasil studi pendahuluan yang dilakukan di SMK 14 Samarinda, didapatkan hasil dari 4 dari 10 orang remaja melakukan perilaku seksual menyimpang dengan lawan jenis yakni berani berpegangan tangan, merangkul dan berpelukkan, dan berciuman. 8 dari 10 remaja mengatakan sering berdiskusi mengenai seksualitas dengan temannya dan mereka mengakui bahwa teman-teman terdekat pernah ciuman, hingga meraba bagian sensitif.

Berdasarkan latar belakang diatas peneliti tertarik untuk melakukan penelitian mengenai hubungan sikap dan peran teman sebaya dengan perilaku seksual pada remaja. 


\section{METODE PENELITIAN}

Rancangan penelitian adalah analitik korelasi dengan penelitian cross sectional.Penelitian ini dilakukan pada bulan Juni 2020 di SMK 14 Samarinda. Adapun teknik sampling penelitian ini menggunakan stratified random sampling dengan menggunakan aplikasi random generator memasukkan nomor responden yang sudah bersedia mengisi di gogglefrom dengan jumlah sampel sebanyak 129 Orang reamaja kelas XI yang tersebar pada 6 kelas.

Instrumen pada penelitian ini menggunakan kuesioner tentang sikap, peran teman sebaya dan perilaku seksual yang telah dilakukan uji validitas dan reabilitas dan dinyatakan valid dan reliabel dengan $r$ hitung > $\mathrm{r}$ tabel pada masing-masing kuesioner. Analisis penelitian ini terdiri dari analisis univariat, dan uji bivariat, untuk menguji hipotesis menggunakan uji statistik Chi-square.

\section{HASIL PENELITIAN DAN PEMBAHASAN} 1. HASIL PENELITIAN

Tabel 1. Distribusi Frekuensi Responden Berdasarkan Sikap

\begin{tabular}{cccc}
\hline No & Sikap & Frekuensi & Persentase (\%) \\
\hline 1 & Positif & 68 & 52,7 \\
2 & Negatif & 61 & 47,3 \\
& Total & 129 & 100.0 \\
\hline
\end{tabular}

Berdasarkan Tabel 1 diatas, didapatkan distribusi sikap tentang perilaku seksual dari 129 responden, didapatkan 68 responden $(52,7 \%)$ memiliki sikap tentang perilaku seksual positif, sedangkan 61 responden $(47,3 \%)$ memiliki sikap tentang perilaku seskual positif.
Tabel 2. Distribusi Frekuensi Responden

\begin{tabular}{cccc}
\multicolumn{4}{c}{ Berdasarkan Peran Teman Sebaya } \\
\hline No & $\begin{array}{c}\text { Peran } \\
\text { Teman } \\
\text { Sebaya }\end{array}$ & Frekuensi & $\begin{array}{c}\text { Persentase } \\
(\%)\end{array}$ \\
\hline 1 & Positif & 63 & 48.8 \\
2 & Negatif & 66 & 51.2 \\
& Total & 129 & 100 \\
\hline
\end{tabular}

Berdasarkan Tabel 2 diatas, didapatkan distribusi peran teman sebaya tentang perilaku seksual dari 129 responden, 65 responden yang memiliki peran teman sebaya negatif dengan persentase (51.2\%).

Tabel 3. Distribusi Frekuensi Responden Berdasarkan Perilaku Seskual

\begin{tabular}{cccc}
\hline No & $\begin{array}{c}\text { Perilaku } \\
\text { Seksual }\end{array}$ & Frekuensi & $\begin{array}{c}\text { Persentase } \\
(\%)\end{array}$ \\
\hline 1 & Beresiko & 85 & 65.9 \\
2 & Tidak Beresiko & 44 & 34,1 \\
& Total & 129 & 100,0 \\
\hline
\end{tabular}

Berdasarkan Tabel 3 diatas, didapatkan distribusi perilaku seksual dari 129 responden, 85 responden yang memiliki perilaku seksual beresiko dengan persentase $(65.9 \%)$, dan 44 responden memiliki perilaku seksual tidak beresiko $(34,1 \%)$.

Tabel 4. Analisis Tabel Hubungan Sikap dengan Perilaku Seksual Remaja

\begin{tabular}{lccccccc}
\hline Sikap & \multicolumn{3}{c}{ Perilaku Seksual } & \multicolumn{2}{c}{ Total } & p value \\
\cline { 2 - 8 } & Beresiko & \multicolumn{9}{c}{$\begin{array}{c}\text { Tidak } \\
\text { Berisiko }\end{array}$} \\
\cline { 2 - 8 } & $\mathrm{N}$ & $\%$ & $\mathrm{~N}$ & $\%$ & $\mathrm{~N}$ & $\%$ & \\
Positif & 45 & 66,2 & 23 & 65,6 & 68 & 100 & \\
Negatif & 40 & 65,6 & 21 & 34,4 & 61 & 100 & \\
Jumlah & 85 & 65,9 & 44 & 34,1 & 129 & 100 & \\
\hline
\end{tabular}


Berdasarkan Tabel 4 diatas diperoleh hasil dari 68 responden yang memilili sikap positif 45 responden $(66,2 \%)$ memiliki perilaku seksual beresiko, hal ini tidak jauh berbeda dari 61 responden yang memiliki sikap negatif, diantaranya 40 responden $(65,6 \%)$ memiliki perilaku seksual beresiko. Hasil analisis bivariat lebih lanjut dengan menggunakan uji Chisquare didapatkan nilai $p$-value $0.943>$ alpha 0,05 dimana artinya tidak ada hubungan yang signifikan sikap dengan perilaku seksual remaja kelas XI di SMKN 14 Samarinda tahun 2020.

Tabel 5. Analisis Tabel Hubungan Peran Teman

\begin{tabular}{|c|c|c|c|c|c|c|c|}
\hline & & $n$ & 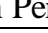 & $\mathrm{aku}$ & $\mathrm{Ks}$ & & aja \\
\hline \multirow{3}{*}{$\begin{array}{c}\text { Peran } \\
\text { Teman } \\
\text { Sebaya }\end{array}$} & \multicolumn{4}{|c|}{ Perilaku Seksual } & \multirow{2}{*}{\multicolumn{2}{|c|}{ Total }} & \multirow{3}{*}{$\begin{array}{c}P \\
\text { value }\end{array}$} \\
\hline & \multicolumn{2}{|c|}{ Berisiko } & \multicolumn{2}{|c|}{$\begin{array}{c}\text { Tidak } \\
\text { Berisiko }\end{array}$} & & & \\
\hline & $\mathrm{N}$ & $\%$ & $\mathrm{~N}$ & $\%$ & $\mathrm{~N}$ & $\%$ & \\
\hline Positif & 31 & 49.2 & 32 & 50.8 & 63 & 100 & \\
\hline Negatif & 54 & 81.8 & 12 & 18.2 & 66 & 100 & 0.000 \\
\hline Jumlah & 85 & 65.9 & 44 & 34.1 & 129 & 100 & \\
\hline
\end{tabular}

Berdasarkan tabel 5 diatas, dari 63 responden yang memiliki peran teman sebaya positif memiliki perilaku seksual yang beresiko lebih kecil yakni 49,2\%, sedangkan dari 66 responden yang memiliki peran teman sebaya yang negative jauh lebih besar memiliki perilaku seksual yang beresiko yakni sebesar $81,8 \%$. Hasil analisis bivariat lebih lanjut dengan menggunakan uji Chi-square didapatkan nilai $p$ value $0.000<$ alpha 0,05 dimana berarti ada hubungan yang signifikan antara peran teman sebaya dengan perilaku seksual remaja kelas XI di SMKN 14 Samarinda tahun 2020.

\section{PEMBAHASAN}

Berdasarkan hasil penelitian diperoleh hasil dari 68 responden yang memilili sikap positif 45 responden $(66,2 \%)$ memiliki perilaku seksual beresiko, hal ini tidak jauh berbeda dari 61 responden yang memiliki sikap negatif, diantaranya 40 responden $(65,6 \%)$ memiliki perilaku seksual beresiko. Hasil analisis bivariat dengan menggunakan uji Chi-square didapatkan nilai $p$-value $0.943>$ alpha 0,05 dimana artinya tidak ada hubungan yang signifikan sikap dengan perilaku seksual remaja kelas XI di SMKN 14 Samarinda tahun 2020.

Sikap seksual adalah respon seksual yang diberikan oleh seseorang setelah melihat, mendengar atau membaca informasi serta pemberitaan, gambar-gambar yang berbau porno dalam wujud suatu orientasi atau kecenderungan dalam bertindak. Sikap yang dimaksud adalah sikap remaja terhadap perilaku seksual (Ramadhani, 2019). Penelitian ini sependapat dengan Samino (2012) dalam analisis perilaku seksual remaja SMAN 14 Bandar lampung 2011 yang menyatakan bahwa tidak ada hubungan sikap seorang wanita dengan perilaku seksual remaja $(p=0.485)$. Berbeda dengan pendapat Misrina, (2020) menjukkan dengan uji chi square ternyata hasil uji dengan $\mathrm{p}$ value $(0,002)<\alpha(0,05)$, hal ini menunjukkan bahwa ada hubungan bermakna antara Sikap Remaja Putri dengan Perilaku Seks Pranikah di Sekolah Menengah Atas Negeri 2 Meuredu Kecamatan Meurah Dua Kabupaten Pidie Jaya Tahun 2020. Ini menunjukkan bahwa seseorang berperilaku pacaran yang berisiko tidak selamanya sesuai dengan pengetahuan dan 
sikapnya karena perilaku seseorang tergantung motivasinya dan peluang untuk melakukannya.

Kuncinya remaja dapat memahami berbagai faktor yang dapat mendukung peningkatan sikap positif dalam dirinya meliputi faktor spiritual, impian, dan antusiasme. yang pada akhirnya hal ini memunculkan kesadaran remaja untuk menjauhi seksual. Menurut Sunaryo (2013) faktor yang mempengaruhi pembentukan dan pengubahan sikap seksual individu meliputi faktor internal dan eksternal. Faktor internal merupakan faktor yang berasal dari dalam individu, dimana individu menerima, mengolah dan memilih segala sesuatu yang datang dari luar. Faktor eksternal merupakan yang berasal dari luar individu, berupa stimulus untuk membentuk dan mengubah sikap. Stimulus dapat berupa langsung misalnya individu dengan individu, atau individu dengan kelompok, dapat juga bersifat tidak langsung yakni melalui perantara, seperti alat komunikasi dan media masa (Rina, 2013).

Dari hasil penelitian ini juga diperoleh bahwa dari 63 responden yang memiliki peran teman sebaya positif memiliki perilaku seksual yang beresiko lebih kecil yakni 49,2\%, sedangkan dari 66 responden yang memiliki peran teman sebaya yang negative jauh lebih besar memiliki perilaku seksual yang beresiko yakni sebesar $81,8 \%$. Hasil analisis bivariat dengan menggunakan uji Chi-square didapatkan nilai $p$ value $0.000<$ alpha 0,05 dimana berarti ada hubungan yang signifikan antara peran teman sebaya dengan perilaku seksual remaja kelas XI di SMKN 14 Samarinda tahun 2020.

Teman sebaya merupakan orang yang dianggap penting oleh remaja masa pertengahan dan akhir, sehingga peran orang tua yang berpengaruh terhadap konsep diri anak semakin sedikit bahkan bisa tergantikan perannya karena di dominasi oleh peran teman sebayanya. Anak semakin mengidentifikasikan diri dengan anakanak seusianya dan mengikuti bentuk-bentuk tingkah laku kelompok teman sebayanya. Remaja akan merasa bahagia jika diterima kawan sebayanya dan sebaliknya akan merasa stress jika dikeluarkan oleh kawan sebayanya (Mariani, 2018).

Peran teman sebaya memiliki peranan yang sangat penting dalam mempengaruhi perilaku siswa karena remaja memiliki kecenderungan sangat tergantung dengan teman-teman sebayanya serta tidak terlibat banyak dengan keluarganya cenderung lebih memiliki keterlibatan seksual, dimana ketergantungan tersebut merupakan faktor yang sangat kuat untuk meramaikan aktivitas seksual mereka (Azis,2017). Dalam hubungan persahabatan, remaja memilih teman yang memiliki kualitas psikologi yang sama dengannya. Apabila kelompok teman sebaya yang diikuti atau yang diimitasinya itu menampilkan sikap dan perilaku yang secara moral atau agama dapat dipertanggung jawabkan, seperti kelompok remaja yang taat beribadah, memiliki budi pekerti luhur, rajin belajar dan aktif dalam kegiatan sosial, maka kemungkinan besar remaja akan menampilkan pribadinya yang baik (Rina, 2013).

Temuan ini sejalan dengan temuan Annisa Nurhayati yang menyatakan bahwa ada hubungan yang bermakna antara hubungan peran teman sebaya dengan perilaku seksual pranikah di SMA Negeri 1 Indralaya Utara. Dan 
dari penelitian Suriani, et al (2016) dengan perhitungan chi square diperoleh $\mathrm{p}$ value $<0,05$ yaitu 0,004, maka dapat disimpulkan bahwa ada hubungan antara pengaruh teman sebaya dengan perilaku gaya pacaran tidak sehat pada remaja usia 12-15 tahun di Kecamatan Tampan Kota Pekanbaru. Adanya hubungan ini dikarenakan siswa SMK sifatnya homogen (teman sekelas relatif sama selama 3 tahun) ditambah jam belajar yang lama menjadikan responden lebih banyak menghabiskan waktu bersama teman sebanya. Peran teman sebaya yang tinggi menjadikan remaja berpotensi mengikuti aktivitas yang dilakukan oleh teman-temannya. (Darmayanti, et.al, 2011).

Dampaknya, remaja dapat terlibat langsung dalam perilaku seksual dikarenakan peran teman sebaya dikenal untuk mengubah kepribadian, sikap dan perilaku remaja. Terdapat bukti yang menunjukkan bahwa di lingkungan masyarakat, perilaku seksual oleh teman sebaya merupakan model untuk perilaku individu dan kadangkadang memberikan tekanan pada seseorang serta menuntutnya untuk terlibat dalam perilaku seksual (Adhikari, 2009). Pada umumnya remaja tersebut melakukannnya hanya sebatas ingin membuktikan bahwa dirinya sama dengan teman-temannya, sehingga dapat diterima menjadi bagian dari anggota kelompoknya seperti yang diinginkan. Selain itu pada usia remaja rasa keingintahuannya begitu besar terhadap seks. Apalagi jika temantemannya mengatakan bahwa seks terasa nikmat, ditambah lagi adanya segala informasi yang tidak terbatas masuknya. Maka rasa penasaran tersebut semakin mendorong mereka untuk lebih jauh lagi melakukan perilaku seksual pranikah Dengan demikian, peran teman sebaya bagi remaja sangat berarti dalam memperoleh informasi yang akan mempengaruhi sikap dan perilaku remaja terhadap isu seksualitas (Kosati, 2018).

\section{SIMPULAN}

Berdasarkan hasil penelitian tidak terdapat hubungan yang signifikan diantara sikap dengan perilaku seksual remaja di SMK kelas XI di SMKN 14 Samarinda tahun 2020 dengan $p$ value $>0,05$, akan tetapi didapatkan hubungan yang signifikan diantara peran teman sebaya dengan perilaku seksual remaja di SMK kelas XI di SMKN 14 Samarinda tahun 2020 dengan $p$ value $<0,05$.

\section{SARAN}

Penelitian ini diharapkan bermanfaat bagi peneliti selanjutnya sebagai sumber data yang terkait perilaku seksual remaja. Melihat banyaknya faktor lain selain sikap dan peran teman sebaya tehadap perilaku seksual remaja, peneliti menyarankan untuk peneliti selanjutnya untuk meneliti faktor-faktor apa saja yang mempengaruhi perilaku seksual pada remaja kemudian menganalisis faktor manakah yang paling dominan dari penyebab perilaku seksual tersebut.

\section{DAFTAR PUSTAKA}

Adhikari R. (2009) Premarital Sexual Behaviour Among College Students Of Kathamandu. M=BMC Publich Health, 9, 241.

Andriyani, A. A. A. M. (2018). Peran Teman Sebaya terhadap Perilaku Seksual Siswa SMA X Jakarta. Jurnal kedokteran dan 
kesehataaan, 14 No. 2.

Aziz, S. (2017). Pendidikan Seks Perspektif Terapi Sufistik Bagi LGBT. Surabaya : CV. Acmad Jaya Group.

Darmayanti, Lestari Y., Ramadani, M., (2011) Peran Teman Sebaya Terhadap Perilaku Seksual Pra Nikah Siswa SLTA Kota Bukittinggi. Jurnal Kesehatan Masyarakat Andalas Vol 6, No 1

Kemenkes. (2018). Survei Demografi dan Kesehatan Indonesia 2017.

Kosati, T.W. (2018). Hubungan antara Peran Orang Tua, Teman Sebaya, dan Religiusitas dengan Perilaku Seksual Beresiko Pada Remaja di SMP Negeri A Surabya. Surabaya : Perpustakaan Universitas Airlangga.

Mariani, N. N. (2018). Peran Orangtua, Pengaruh Teman Sebaya, dan Sikap Berhubungan dengan Perilaku Seksual Pranikah pada Siswa-siswi SMA N 1 Jamblang Kabupaten Cirebon. jurnal kebidanan, vol 6 no 2.

Mariani, N. N., \& Murtadho, S. F. (2018). Hubungan Antara Peran Orang Tua, Pengaruh Teman Sebaya, Dan Sikap Terhadap Perilaku Seksual Pranikah Pada Siswa-Siswi Sma Negeri 1 Jamblang Kabupaten Cirebon Tahun 2017. journal article, 6(2), 116.

Misrina, Safira S. (2020). Hubungan Pengetahuan Dan Sikap Remaja Putri Dengan Perilaku Seks Pranikah Di Sekolah Menengah Atas Negeri 2 Mereudu Kecamatan Meurah Dua Kabupaten Pidie Jaya. Journal of Healthcare Technology and Medicine Vol. 6 No. 1
Rina, N. D. (2013). Faktor-Faktor yang Mempengaruhi Sikap Remaja Terhadap Seks Pranikah. Journal Online Mahasiswa Perpustakaan Fakultas Keperawatan. Vol 1 No 1.

Nurwati \& Parellangi, E. R. B. L. (2019). No Title. jurnal kebidanan, 1-12.

Ramadhani, A. (2019). Pengaruh Sikap Terhadap Perilaku Seksual Pranikah pada Remaja di Kota Banyuwangi. Jurnal Iilmiah Ilmu Pendidikan Dan Sosial, Vol 8 no 1.

Samino. (2012) . Analisis Perilaku Sex Remaja SMAN 14 Bandarlampung 2011. Jurnal Dunia Kesmas. Vol 1 No 4.

Sunaryo. 2013. Psikologi untuk keperawatan. Jakarta: EGC

Suriani, L., Effendi, I., Yuningsih, S. A. (2016) Faktor-Faktor Yang Berhubungan Dengan Perilaku Gaya Pacaran Tidak Sehat Pada Remaja Usia 12-15 Tahun Di Kecamatan Tampan Pekanbaru. Jurnal Al-Insyirah Midwifery. Vol 5 No 1.

Zakiah, U. H. N. F. (2020). Gambaran Kehamilan Remaja Ditinjau Dari Umur, Penyebab Kehamilan Dan Kontak Pertama Dengan Tenaga Kesehatan Di Wilayah Kerja Puskemas Sikumana Kota Kupang. Jurnal Kebidanan, 3 Nomor 1. 